\title{
The new stem-group brachiopod Oymurania from the lower Cambrian of Siberia
}

Artem Kouchinsky, Lars E. Holmer, Michael Steiner, and Galina T. Ushatinskaya

Acta Palaeontologica Polonica 60 (4), 2015: 963-980 doi:http://dx.doi.org/10.4202/app.00037.2013

A stem-group brachiopod, Oymurania gravestocki Ushatinskaya gen. et sp. nov. is described herein from the middle Atdabanian-lower Botoman Stages ( Cambrian Stage 3) of the Siberian Platform. The fossils were extracted from limestone beds of the Emyaksin, Perekhod, and Pestrotsvet formations as assemblages of disarticulated orthoconic to cyrtoconic porous shells in apatite preservation. The originally organophosphatic shells of Oymurania are externally similar to mitral sclerites (ventral valves) of the stem-group brachiopod Micrina , although no sellate-like sclerites, nor differentiated subapical area with apophyses were recognised in our material. The range of Oymurania shells with subcentral to posteromarginal apex is similar to that of ventral valves of Mickwitzia. Oymurania is also characterised by the system of radial and orthogonal canals open in pairs or triplets in small depressions or indentations of growth lamellae in the outer shell surface. The orthogonal (Micrina-Setatella type) and radial (horizontal setigerous tubes) canals are widespread among the early Cambrian stem-group brachiopods, such as Micrina, Mickwitzia, and Setatella. In addition to these canals, Oymurania exhibits a well-developed acrotretoid columnar microstructure, also known from Setatella. A broad subapical platform in cyrtoconic shells (presumably ventral valves) of Oymurania is interpreted homologous to the deltoid area in mitrals of Micrina and pseudointerarea/interarea in ventral valves of Setatella /paterinid brachiopods. Except with probable cell imprints and openings of orthogonal canals, no morphological differentiation was, however, reflected by the shell interior of Oymurania gravestocki . Being closely related to tannuolinids and mickwitziids, Oymurania complements the picture of diversification of the early Cambrian stem-group brachiopods that occurred in parallel with radiation of paterinids and other crow-group brachiopods on the Siberian Platform and worldwide.

Key words: Brachiopoda, Oymurania, Mickwitzia, Micrina, Setatella, Cambrian, Siberia.

Artem Kouchinsky [artem.kouchinsky@nrm.se], Department of Palaeobiology,

Swedish Museum of Natural History, Box 50007, SE-104 05 Stockholm,

Sweden; Lars E. Holmer [Lars.Holmer@ pal.uu.se], Department of Earth

Sciences, Palaeobiology, Uppsala University, Villavägen 16, SE-752 36

Uppsala, Sweden; Michael Steiner [Michael.Steiner@FU-Berlin.de], Department of 
Earth Sciences, Freie Universität Berlin, Malteserstrasse 74-100, Haus D, Berlin, 12249, Germany; Galina T. Ushatinskaya [gushat@paleo.ru], Paleontological Institute, Russian Academy of Sciences, Profsoyuznaya ul. 123, Moscow 117997, Russia.

This is an open-access article distributed under the terms of the Creative Commons Attribution License (for details please see creativecommons.org), which permits unrestricted use, distribution, and reproduction in any medium, provided the original author and source are credited.

For Full text $(2,404.3 \mathrm{kB})$ 